\title{
Notes
}

\section{HOW PERMANENT BECAME TEMPORARY IN DEL MONTE DUNES}

\author{
MichaEl C. LEVINE
}

\begin{abstract}
Regulatory takings are like car accidents. They fascinate us. We cannot help slowing down to look. What a disaster, we say to ourselves. We are so glad it did not happen to us. But we wonder if we could be next. We think about who is at fault, who should pay for the damages, and how it all could have been avoided in the first place. And we question how the rules of the road could be improved so that such collisions in the future could be averted. ${ }^{1}$
\end{abstract}

The concept of a regulatory taking was first recognized in the late $1800 \mathrm{~s}^{2}$ In the century since, innumerable federal judges, professors, and other commentators have managed so to convolute that area of the law that it does, indeed, resemble a car wreck or an impenetrable jungle rather than a discrete legal principle. In fact, it has been written that " $[\mathrm{t}] \mathrm{hroughout}$ constitutional jurisprudence, only the right of privacy can compete seriously with takings law for the doctrine-in-most-desperate-need-of-a-principle prize."

1. G. Richard Hill, Partial Takings After Dolan, in TAKINGS: LAND-DEVELOPMENT Conditions AND Regulatory TAKings AFTer Dolan AND LUCAS 189, 189 (David L. Callies ed., 1996) [hereinafter TAKINGS AFTER DOLAN AND LUCAS].

2. Mugler v. Kansas, 123 U.S. 623 (1887), is widely recognized as the first Supreme Court case to acknowledge that a regulatory taking was possible. See Terri L. Lindfors, PropertyRegulatory Takings and the Expansion of Burdens on Common Citizens, 24 WM. MITCHELL L. REV. 255, 260 (1998).

3. Jed Rubenfeld, Usings, 102 YALE L.J. 1077, 1081 (1993); see also BRUCE A. ACKERMAN, PRIVATE PROPERTY AND THE CONSTITUTION 8 (1977) ("I have not encountered a single lawyer, judge, or scholar who views existing case-law as anything but a chaos of confused argument which ought to be set right if one only knew how."); Richard L. Settle, Regulatory Taking Doctrine in Washington: Now You See It, Now You Don't, 12 U. PUGET Sound L. REV. 339, 339 ("Regulatory taking doctrine is the most perplexing area of American land use law."). 
At first, it is difficult to imagine how and why takings law has fallen into such disarray. The Fifth Amendment's admonition that "[n]or shall private property be taken for public use, without just compensation," ${ }^{4}$ seems simple enough. Indeed, Professor Laurence Tribe has stated that "[m] st people know a taking when they see one, or at least they think they do." ${ }^{5}$ However, recognizing the circumstances that may give rise to a constitutional deprivation is only the initial step in a takings analysis. One must then establish whether the perceived injury is temporary or permanent, regulatory or physical, and determine which standards apply to decide if the violation was, indeed, a taking. It is in resolving these questions that much of the confusion arises.

In particular, the distinction between temporary and permanent regulatory takings has become blurred by increasingly complex factual situations. ${ }^{6}$ The Court's simple definition of temporary regulatory takings as involving regulations ultimately "abandon[ed] by the government" is no longer sufficient. Nor is the increasing reliance upon the assertion that "temporary reversible 'takings' should be analyzed according to the same constitutional framework applied to permanent irreversible "takings." " made apparent by the Supreme Court's recent holding in City of Monterey v. Del Monte Dunes, Ltd. ${ }^{9}$

Briefly, the Del Monte Dunes litigation involved a jury verdict requiring the city of Monterey to compensate a developer $\$ 1.45$ million for the five years between the city's final denial of a building permit and the developer's sale of the property to the state of California. ${ }^{10}$ While it is clear that compensation was awarded for a finite period of time, the court never characterized the taking as permanent

4. U.S. CONST. amend. V.

5. Laurence H. Tribe, American Constitutional Law 592 (2d ed. 1988).

6. See generally Gregory M. Stein, Pinpointing the Beginning and Ending of a Temporary Regulatory Taking, 70 WASH. L. REV. 953 (1996) (noting this phenomenon and proposing the use of case law to determine the point at which a regulatory taking begins and ends).

7. First English Evangelical Lutheran Church v. County of Los Angeles, 482 U.S. 304, 318 (1987). In contrast, a permanent regulatory taking is effected by a regulation which the government cannot, or chooses not to, "abandon." For example, a city's insistence that a landowner devote a portion of its land to a bike path would effect a permanent regulatory taking. See Dolan v. City of Tigard, 512 U.S. 374, 384 (1984).

8. San Diego Gas \& Elec. Co. v. City of San Diego, 450 U.S. 621, 657 (1981) (Brennan, J., dissenting).

9. 119 S. Ct. 1624 (1999) [hereinafter 
or temporary. ${ }^{11}$ Similarly, in upholding the verdict, the Ninth Circuit Court of Appeals did not once refer to the city's action as a "temporary taking." $" 12$ Rather, it found solely that a reasonable jury could have determined that the city's actions met the criteria for a permanent regulatory taking. ${ }^{13}$ The Supreme Court, also without analyzing the nature of the takings claim, affirmed the decision. ${ }^{14}$ In fact, in its opinion, the Court assumed that the taking was temporary and expressly declined "to define with precision the elements of a temporary regulatory takings claim." 15

However, Del Monte Dunes does not involve a typical temporary regulatory taking. While the taking was assumed to be temporary because compensation was sought for a finite period of time, there was no "abandoned" regulation. Rather, the compensatory period was limited by the developer's sale of the plot of land. Further, inherent in each court's analysis was the understanding that the landowner would never be able to develop the specified plot of land. ${ }^{16}$ Because this scenario has elements of both a permanent and temporary taking, it presented an ideal opportunity for the Supreme Court to distinguish between the two explicitly. However, the Court chose not to take that opportunity, and thereby missed an excellent chance to provide guidance and clarification in this convoluted area of the law. Also, by allowing a landowner, rather than the city, to terminate the taking, the Court expanded the realm of compensable temporary takings without so much as a word of explanation for its decision to do so. Although this issue was not raised in the petition for certiorari, the Court should have used its opinion to refine its takings jurisprudence.

To explain the action that should have been taken by the Court, Part I of this Note will provide a brief outline of the Del Monte Dunes litigation. Part II will then examine the current state of regulatory takings jurisprudence, paying special attention to the futility exception to the final agency action requirement. Part III will follow by explaining that Del Monte Dunes did not involve a typical temporary

11. See id. (reproducing the district court's jury instruction, which focused on whether the plaintiff was denied all economically viable use of the property without distinguishing temporary from permanent loss).

12. See Del Monte Dunes, Ltd. v. City of Monterey, 95 F.3d 1422, 1430-34 (9th Cir. 1996) [hereinafter Del Monte Dunes II].

13. See id. at 1434.

14. See Del Monte Dunes III, 119 S. Ct. at 1634.

15. Id. at 1644

16. See infra notes $36-37$ and accompanying text. 
taking. This part will demonstrate how the judicial analyses and procedural posture of the case led to confusion between temporary and permanent takings law. Finally, Part IV will conclude that the Court need not have developed a new substantive analysis to dispel this confusion, but, rather, should have drawn more concrete boundaries between permanent and temporary takings. The Court could have explained that this situation was a new sort of temporary taking in which the landowner was permitted to remove the government's choice to rescind the offending regulation. Alternatively, the Court might have stated explicitly that the case did not involve a temporary taking at all, but a permanent taking for which the developer was allowed compensation only for a limited time. The second option is preferable because it would have allowed the Court to make use of its existing jurisprudence without expanding the realm of compensable temporary takings.

\section{A BRIEF InTRODUCTION TO DEL MONTE DUNES}

Monterey, California, was the focal point for the latest battle in the ongoing saga of takings jurisprudence. For twelve years prior to being heard in the Supreme Court, the city of Monterey was locked in litigation with developers over a 37.6-acre plot of ocean-front land known as the "Dunes." agreement over building permits that led to a lawsuit in the United States District Court for the Northern District of California. The case was heard twice by the Ninth Circuit Court of Appeals and decided finally by the Supreme Court in May $1999 .{ }^{18}$ In that time, however, not one court addressed the distinction between temporary and permanent regulatory takings. To understand fully the opportunity presented to the Supreme Court to distinguish explicitly between these two types of regulatory takings, it is necessary to sort through some of the details of the litigation.

This procedural nightmare began in 1981 when Ponderosa Homes, then the owner of the Dunes, applied for a permit to build 344 residential units at that location. ${ }^{19}$ Although the 344-unit proposal

17. See Del Monte Dunes, Ltd. v. City of Monterey, 920 F.2d 1496, 1499 (9th Cir. 1990) [hereinafter Del Monte Dunes I]. Apparently, the land was previously used as a dumping ground for empty oil storage tanks. See David G. Savage, Land of Opportunity: Can Property Owners Sue over a City's Regulatory Decision?, A.B.A. J., Oct. 1998, at 35.

18. See Del Monte Dunes III, 119 S. Ct. at 1645.

19. See Del Monte Dunes I, 920 F.2d at 1499. 
was within the density limits imposed by the existing zoning ordinance, the city planning commission denied the permit. ${ }^{20}$ The city, however, indicated that a proposal for development of 264 units would be looked upon more favorably. ${ }^{21}$ Ponderosa then submitted such a proposal, and it was promptly rejected. ${ }^{22}$ Again following the city planner's advice, Ponderosa next submitted a plan for 224 units. ${ }^{23}$ Once more, the city planning commission denied the building permit. ${ }^{24}$ Ponderosa appealed that determination to the city council, which requested that the commission consider a proposal for 190 units. ${ }^{25}$ While this proposal was under evaluation, Del Monte Dunes at Monterey ("Del Monte"), the plaintiffs in the litigation, purchased the Dunes from Ponderosa and pursued the application. ${ }^{26}$ The change in ownership did not affect the developer's luck, however, as the city planning commission once again rejected the development proposal. ${ }^{27}$

In September 1984, three years after the original development proposal, the city council overruled the planning commission and approved the plan for 190 residential units. ${ }^{28}$ The approval was subject to Del Monte's fulfilling several conditions prior to developing, including access requirements, fencing and grading specifications, and the provision of moderate-income housing. ${ }^{29}$ Further, Del Monte was required to obtain approval of a plan to conserve the habitat of the Smith's Blue Butterfly, an endangered species thought to inhabit the area. ${ }^{30}$ Del Monte then submitted a revised project plan that it hoped would meet the conditions imposed by the city council. Despite a favorable review by its professional staff, the planning commission denied a permit for the new proposal in January $1986 .{ }^{31}$

\footnotetext{
20. See id. at 1502 .

21. See id.

22. See id.

23. See id.

24. See id.

25. See id.

26. See id. at 1499 .

27. See id. at 1502 .

28. See id. In overruling the planning commission, the city council granted Del Monte an 18-month use permit. See id.

29. See id. at 1503 .

30. See id.

31. See id.
} 
Del Monte appealed this decision to the city council, which upheld the planning commission's determination. ${ }^{32}$ Del Monte then filed suit in the District Court for the Northern District of California, claiming that the permit denial effected a regulatory taking, violated the Equal Protection and Due Process Clauses of the Fourteenth Amendment, and violated the common law principles of estoppel and unjust enrichment. ${ }^{33}$ In support of these claims, the developer's attorney stated that "his clients were given a runaround by the city planing commission and the city council" and, specifically, that "[e]very time they satisfied one condition [to win the permit], the city came up with a new one." ${ }^{34}$ Despite Del Monte's assertions that the city would never allow it to build on the Dunes, the district court dismissed the claims as unripe because the city had not issued a final permit denial. ${ }^{35}$ Del Monte appealed this determination to the Ninth Circuit as it related to the takings, due process, and equal protection claims.

The Ninth Circuit found the claims ripe for review because any further reapplication would have been futile. ${ }^{36}$ The court went on to state that "[r]equiring appellants to persist with this protracted application process to meet the [finality] requirement would implicate the concerns about disjointed, repetitive, and unfair procedures" that the futility exception was designed to prevent. ${ }^{37}$ Further, the court held that "the failure to seek a variance [did] not affect the ripeness of appellants' claim" because the "proposed development did not conflict with express terms in the city's zoning ordinances or its general land

32. See id. The city council denied the permit for six reasons: (1) necessary sand relocation would cause unmitigable environmental damage; (2) development would impact flora and fauna in ways that would not be adequately mitigated; (3) the plan did not provide adequate access to and from the property; (4) the development was likely to cause damage to the Smith's Blue Butterfly habitat; (5) the project did not conform with the General Plan because it did not protect important flora and fauna; and (6) no showing of overriding considerations was made such that the project should be allowed to proceed in light of the environmental damage it would cause. See id. at 1504-05.

33. See id. at 1500 .

34. Savage, supra note 17 , at 35 . As one commentator put it:

Building on the high ground was rejected because the homes could be seen from the highway .... Building near the ocean was rejected because the beach must be preserved for the public's use .... And the remaining acres - a sunken-bowl area in the center of the dunes - were said to be a home for the endangered, and elusive, Smith's Blue Butterfly.

Id.

35. See Del Monte Dunes I, 920 F.2d at 1500.

36. See id. at 1506

37. Id. 
use plan. ${ }^{, 38}$ In so holding, the court rejected the city's assertion that Del Monte's claim was not ripe because it had not submitted enough proposals to pinpoint the exact level of development that the city would allow. ${ }^{39}$

The case was then remanded to the district court for trial. The trial judge disposed of Del Monte's substantive due process claim ${ }^{40}$ and ordered the equal protection and takings claims tried to a jury. ${ }^{41}$ Prior to trial, Del Monte sold the Dunes to the state of California for $\$ 4.5$ million, which was $\$ 800,000$ more than it had paid for the land seven years earlier. ${ }^{42}$ Despite the sale, Del Monte continued with its claim, and the case went to trial in early $1994 .^{43}$ The jury, instructed separately on the takings and equal protection claims, returned a verdict in favor of Del Monte for $\$ 1.45$ million. ${ }^{44}$ This award was ostensibly for damages suffered between the 1986 denial of the final permit application and Del Monte's 1991 sale of the property. It also "resulted from the City's liability for both the takings and the equal protection claims."

The city promptly appealed to the Ninth Circuit, which affirmed the award. ${ }^{46}$ The city's timely petition for certiorari was granted solely to resolve the regulatory takings issues. ${ }^{47}$ The following questions were presented to the Court for review:

\footnotetext{
38. Id. at 1502 .

39. See id.

40. The judge found that the city did not violate Del Monte's due process rights because it asserted valid regulatory reasons for denying the construction permit. See Del Monte Dunes II, 95 F.3d 1422, 1425 (9th Cir. 1996).

41. See id.

42. See Savage, supra note 17 , at 35 .

43. See id.

44. See Del Monte Dunes II, 95 F.3d at 1425-26.

45. Id. at 1426 .

46. In relevant part, the court found that a reasonable jury could have found a taking on either of the two grounds put to it. That is, the court determined that there was sufficient evidence such that a jury could have found a taking either because "the City's denial of Del Monte's application lacked a sufficient nexus with its stated objectives," or "because it denied Del Monte all economically viable use of its property." Id. at 1432. The court also determined that the trial court did not err by submitting the inverse condemnation claim, and specifically the issue of liability, to a jury. See id. at 1426-30. In addition, the court used the "rough proportionality" test and upheld the damage award as reasonable. See Del Monte Dunes II, 95 F.3d at 1435. See Dolan v. City of Tigard, 512 U.S. 374 (1994), for an explanation of the rough proportionality test.

47. See Del Monte Dunes, Ltd. v. City of Monterey, 118 S. Ct. 1359 (1998) (granting certiorari).
} 
(1) whether issues of liability were properly submitted to the jury ...

(2) whether the Court of Appeals impermissibly based its decision on a standard that allowed the jury to reweigh the reasonableness of the city's land-use decision, and (3) whether the Court of Appeals erred in assuming that the rough-proportionality standard... applied to this case ....

The Court found in favor of upholding the award on each of the first two issues and, on the third, found that the Dolan roughproportionality standard, while not properly extended beyond the context of exactions, was inapposite in this case. ${ }^{49}$ In making these determinations, however, the Court expressly declined to provide an analytical framework for temporary regulatory takings. ${ }^{50}$ In fact, the Court did not discuss any distinction between temporary and permanent regulatory takings analyses.

\section{THE JUMBLED JURISPRUDENCE OF REGULATORY TAKINGS}

Del Monte Dunes is only the latest chapter in the judiciary's continuing effort to explain takings law. Numerous judges and commentators have attempted to develop an analytic framework for takings jurisprudence. ${ }^{51}$ None, however, has provided a satisfactory method for distinguishing temporary from permanent regulatory takings. By refusing to make explicit an analytic framework for temporary regulatory takings in Del Monte Dunes, the Supreme Court missed an opportunity to simplify this area of the law. To appreciate fully the niche into which the Del Monte Dunes litigation fits, one must first understand the fundamentals of permanent and temporary takings analysis.

\footnotetext{
48. Del Monte Dunes III, 119 S. Ct. 1624, 1635 (1999).

49. See id. at 1635-37. Briefly, the rough-proportionality standard requires that, when a government agency compels a landowner to surrender a portion of his land in furtherance of a legitimate governmental objective, the required exaction must be proportional to the benefit achieved. See Dolan, 512 U.S. at 391 ("No precise mathematical calculation is required, but the city must make some sort of individualized determination that the required dedication is related both in nature and extent to the impact of the proposed development.").

50. See Del Monte Dunes III, 119 S. Ct. at 1644 (stating that "[t]he posture of the case does not present an appropriate occasion to define with precision the elements of a temporary regulatory takings claim"); see also id. at 1636 ("The city did not challenge below the applicability or continued viability of the general test for regulatory takings liability .... Given the posture of the case before us, we decline the suggestions of amici to revisit these precedents.").

51. See, e.g., Lucas v. South Carolina Coastal Council, 505 U.S. 1003 (1992); Rubenfeld, supra note 3; Stein, supra note 6.
} 


\section{A. Analyzing Physical and Regulatory Takings}

At the most basic level, a taking can be either physical or regulatory and either permanent or temporary. ${ }^{52}$ The law surrounding physical takings, both permanent and temporary, has been fairly well settled for some time. ${ }^{53}$ The simplest physical taking occurs when a government exercises its power of eminent domain to occupy private property "in the name of some ostensible public good." that such occupations require compensation. Thus, when the government takes property permanently-for example, to build a road-it must compensate the landowner by paying him fair market value. It also must compensate a landowner if the physical invasion is temporary. Thus, when the government occupies a home or place of business temporarily-for instance, during a time of war-it generally must pay fair rental value for that time.

An overt physical invasion, however, is only one type of compensable taking. Since the late $1800 \mathrm{~s},{ }^{56}$ courts have recognized that a government also might take private property indirectly by regulating it too stringently. However, the principles applicable to regulatory takings are much less clearly defined than those pertaining to physical occupations. These rules are complicated by the fact that state and local governments are unquestionably authorized to undertake some degree of land-use planning and regulation. ${ }^{57}$ Thus, the simple issu-

52. See, e.g., Lindfors, supra note 2, at 262 ("Cases interpreting the Fifth Amendment Takings Clause have generally distinguished between physical occupations authorized by the government and governmental regulations of property use."); see also Kimball Laundry Co. v. United States, 338 U.S. 1, 1-2 (1949) (recognizing that a landowner could be deprived of his property temporarily).

53. See Rubenfeld, supra note 3, at 1081 ("The most historically settled application of the Just Compensation Clause-indeed perhaps the only historically settled application-is the requirement that government must pay for property it seizes through an exercise of eminent domain.").

54. Id.

55. See, e.g., Kimball Laundry Co. v. United States, 338 U.S. 1, 1-2 (1949) (holding that the federal government was required to compensate for lost rent as well as lost "trade routes" when it occupied a laundry during World War II); United States v. General Motors Corp., 323 U.S. 373, 382-83 (1945) (determining that the government owed compensation for its temporary occupation of part of a General Motors plant equal to the amount of rent that could have been earned over that time for that part of a similarly equipped facility).

56. See supra note 2.

57. See Dolan v. City of Tigard, 512 U.S. 374, 384 (1994) (reasoning that "the authority of state and local governments to engage in land use planning has been sustained against constitutional challenge" since 1926 (citing Village of Euclid v. Ambler Realty Co., 272 U.S. 365 (1926)); see also Keystone Bituminous Coal Ass'n v. DeBenedictis, 480 U.S. 470, 491-92 (1987) ("Long ago it was recognized that 'all property in this country is held under the implied obliga- 
ance of a restrictive zoning ordinance, without a particularized showing of harm, does not constitute a taking. ${ }^{58}$ Further, because regulatory situations are factually distinct, courts have been reluctant to issue categorical rules. ${ }^{59}$ Thus, since 1922, "[t]he general rule at least [has been], that while property may be regulated to a certain extent, if regulation goes too far it will be recognized as a taking." ${ }^{60}$ However, in the seventy-five years since Justice Holmes established this oftquoted standard, courts have struggled to determine just how far is "too far."

Despite the dearth of precise rules, a general framework has been developed in which to make this determination. Essentially, the court undertakes a two-tiered analysis when deciding whether a regulation effects a taking. It looks first to the character of the governmental action and, second, to the impact of that action on the landowner. Initially, then, a court "explores the legitimacy of the governmental action" and determines "whether the purpose of the regulatory action is a 'legitimate state interest' and ... whether the means used to achieve the objective 'substantially advances' the intended purpose." ${ }^{\text {"11 }}$ Although all sides in the Del Monte Dunes litigation agree that the city was advancing a legitimate state interest by restricting development and preserving natural habitat, there was significant disagreement about whether the permit denials substantially advanced that purpose. ${ }^{62}$

tion that the owner's use of it shall not be injurious to the community." (quoting Mugler v. Kansas, 123 U.S. 623, 665 (1887)).

58. See Agins v. City of Tiburon, 447 U.S. 255, 260 (1980) (finding that a general zoning ordinance that allowed only one house per five-acre plot did not constitute a taking because it advanced a legitimate public interest); see also Hodel v. Virginia Surface Mining \& Reclamation Ass'n, 452 U.S. 264, 294-95 (1981) (finding a takings claim to be fatally deficient because the claimant did not identify any particular land that was affected by the regulation but, rather, simply challenged it generally).

59. See, e.g., Lucas v. South Carolina Coastal Council, 505 U.S. 1003, 1047 (1992) (Blackmun, J., dissenting).

60. Pennsylvania Coal Co. v. Mahon, 260 U.S. 393, 415 (1922) (declaring unconstitutional a Pennsylvania law that prohibited the mining of underground coal reserves if that mining would result in surface subsidence).

61. Robert H. Freilich et al., Regulatory Takings: Factoring Partial Deprivations into the Taking Equation, in TAKINGS AFTER DOLAN AND LUCAS, supra note 1, at 165, 166.

62. See Del Monte Dunes II, 95 F.3d 1422, 1430 (9th Cir. 1996) ("For purposes of review[] ... we assume that the City's stated interests of protecting the environment and health and safety of its citizens were legitimate."). While the debate about whether the method chosen by the city "substantially advances" this purpose was very much alive in the Supreme Court, the inquiry does not factor into the analysis undertaken in this Note. Rather, the "substantially ad- 
If the legitimacy prong is met, the court will then analyze the impact of the regulation on the property owner. Generally, it will do so by examining the character of the governmental action, the economic impact on the property owner, and any interference with the owner's investment-backed expectations. ${ }^{63}$ If the impact is disproportionate to the state interest advanced, a taking will be found. However, in Lucas v. South Carolina Coastal Council, ${ }^{64}$ the Supreme Court determined that there exist "two discrete categories of regulatory action [that are] compensable without case-specific inquiry." ${ }^{65}$ First, any regulation that subjects a landowner to a "physical invasion" of his property is considered, per se, to constitute a taking. ${ }^{66}$ Second, and more important for purposes of this Note, "per se" takings also encompass regulations that deny a landowner "all economically beneficial or productive use of land." "If either of these per se situations has occurred, the court will decree a taking, and the inquiry will cease." ${ }^{68}$ Thus, the Court in Del Monte Dunes was not required to balance the three factors because the landowners claimed that the permit denials effected a per se taking by denying them "all economically viable use" of the land. ${ }^{69}$

vances" analysis informs the debate surrounding the applicability of the Dolan roughproportionality standard to zoning regulations. See id.

63. See Penn Cent. Transp. Co. v. New York City, 438 U.S. 104 (1978) (establishing the ad hoc, factual inquiry for regulatory takings); Freilich et al., supra note 61, at 178; see also Dodd v. Hood River County, 136 F.3d 1219, 1228 (9th Cir. 1998) ("[W]hen a government regulation prohibits something less than all economically beneficial use and causes at most a partial loss in economic use, the fact that there has been no categorical taking does not end the analysis under federal law.").

64. 505 U.S. 1003 (1992).

65. Id. at 1015 .

66. Id. The epitome of a "physical invasion" per se takings case is Loretto $v$. Teleprompter Manhattan CATV Corp., 458 U.S. 419 (1982). In Loretto, the Court found that landowners must be compensated when a regulation required them to allow installation of cable equipment in their buildings. See id. at 421 .

67. Lucas, 505 U.S. at 1015.

68. Freilich et al., supra note 61, at 166.

69. The landowner also claimed that the permit denials did not substantially advance the legitimate state interest. See Del Monte Dunes II, 95 F.3d 1422, 1428 (9th Cir. 1996). The litigation proceeded according to the rule established in Outdoor Systems, Inc. v. City of Mesa, 997 F.2d 604 (9th Cir. 1993), which provides that "[a] zoning law effects a taking if (1) it does not substantially advance a legitimate governmental interest; or (2) it denies an owner economically viable use of his land." Id. at 615 (citing Agins v. City of Tiburon, 447 U.S. 255, 260 (1980)). 


\section{B. Temporary Regulatory Takings}

The framework for regulatory takings analysis described above was developed in reference to permanent takings. However, not all regulations are put in place permanently. Thus, "a regulatory 'taking' may be temporary, by virtue of the government's power to rescind or amend the regulation." ${ }^{, 70}$ For many years, such temporary takings were not recognized as constitutional deprivations. Thus, a regulation that prevented economic use of property for a period of time and was then declared invalid or rescinded was not considered to effect a compensable taking. However, in First English Evangelical Lutheran Church v. County of Los Angeles, ${ }^{71}$ the Supreme Court found explicitly that "[i]nvalidation of the ordinance... though converting the taking into a 'temporary' one, is not a sufficient remedy to meet the demands of the Just Compensation Clause." takings which ... deny a landowner all use of his property[] are not different in kind from permanent takings, for which the Constitution clearly requires compensation."

First English revolutionized takings jurisprudence by allowing monetary compensation in circumstances in which only injunctive relief or invalidation had been available previously. In so doing, it also contributed mightily to the growing confusion surrounding takings law. While courts have generally found that "temporary reversible 'takings' should be analyzed according to the same constitutional framework applied to permanent irreversible 'takings,", ${ }^{74}$ they have had to adapt the determinative framework described above to apply it to temporary takings. ${ }^{75}$ In addition, courts have had to develop en-

70. San Diego Gas \& Elec. Co. v. City of San Diego, 450 U.S. 621, 657 (1981) (Brennan, J., dissenting).

71. 482 U.S. 304 (1987).

72. Id. at 319. In First English, the plaintiff church owned land on which it administered a campground. After a flood destroyed the campground buildings, Los Angeles County instituted a temporary regulation prohibiting reconstruction of buildings in a flood control area. The church filed suit complaining that the ordinance effected a taking. The Supreme Court found that if the ordinance effected a taking, simply invalidating it was an insufficient remedy and the church was entitled to monetary compensation for the period of time during which it was in effect. See id. at 307-08, 319.

73. Id. at 318; see also San Diego Gas \& Electric, 450 U.S. at 657 (Brennan, J., dissenting) ("Nothing in the Just Compensation Clause suggests that 'takings' must be permanent and irrevocable.").

74. San Diego Gas \& Electric, 450 U.S. at 657 (Brennan, J., dissenting).

75. The framework is complicated in the context of a reversible regulation because it becomes increasingly difficult to separate a temporary taking from a permissible land-use ordi- 
tirely new formulae for determining "just compensation." Compensating for a permanent taking involves the relatively simple task of determining the fair market value of the property at the time of the taking. ${ }^{76}$ However, adding a temporal element to the calculation makes it significantly more difficult. ${ }^{77}$

Finally, courts also must determine the beginning and end of a temporary taking. Unfortunately, however, while the Court has made it clear that the government must compensate a landowner for the period during which the taking is effective, ${ }^{78}$ it "has offered little guidance as to when a temporary regulatory taking begins and ends." 79 This problem is particularly significant in the current context because ill-defined temporal boundaries may blur the distinction between permanent and temporary takings. In this case, for example, the plaintiffs could have claimed that the taking began at almost any point during the five years in which they were applying for a building permit. To make matters worse, this problem may affect the point at which the temporary takings claim becomes ripe for adjudication.

\section{Ripeness and the Futility Exception}

To prove that a regulatory takings claim is ripe for review, a plaintiff must show that "the government entity charged with implementing the regulations has reached a final decision regarding the application of the regulations to the property at issue." ${ }^{80}$ The finality re-

nance. Lucas was decided after First English and was intended, at least partly, to help stem the burgeoning confusion. The Court's success or failure in this endeavor is discussed at some length below. See infra notes $96-99$ and accompanying text.

76. See Wheeler v. City of Pleasant Grove, 833 F.2d 267, 271 (11th Cir. 1987) (instructing that the "trial court should award 'market rate return computed over the period of the temporary taking on the difference between the property's fair market value without the regulatory restriction and its fair market value with the restriction'" (quoting Nemmers v. City of Dubuque, 764 F.2d 502, 505 (8th Cir. 1985))).

77. See Nathaniel S. Lawrence, Regulatory Takings: Beyond the Balancing Test, in REGUlATORY TAKING: THE LiMITS OF LAND USE CONTROLS 191, 232-33 (G. Richard Hill ed., 1990) ("[First English] also poses difficult problems of valuation. It remains to be decided, for example, to what degree compensation awards should be off-set to reflect less drastic restrictions the government could validly have imposed."). Also, rental values are not easy to calculate, and the blurred boundaries may make it difficult to include lost income.

78. See First English, 482 U.S. at 319.

79. Stein, supra note 6 , at 957.

80. Hoehne v. County of San Benito, 870 F.2d 529, 532 (9th Cir. 1989). The landowner must also show that he has pursued compensation through any available state procedures. See Suitum v. Tahoe Reg'l Planning Agency, 520 U.S. 725, 734 (1997) (“[A] plaintiff must demonstrate that she has both received a 'final decision regarding the application of the [challenged] 
quirement ensures justiciability by guaranteeing that the agency will not suddenly change its mind. It is also "necessary to allow the court to evaluate the 'economic impact' and the extent of the challenged regulation's interference with 'reasonable investment-backed expectations." " 81

"The focus of the 'final decision' inquiry is on ascertaining the extent of the governmental restriction on land use." ${ }^{, 2}$ Thus, in the development context, the finality requirement is generally met by a showing that the landowner had permit and variance requests denied and that there was "a final and authoritative determination of the type and intensity of development legally permitted on the subject property." ${ }^{, 83}$ However, such a showing is not always required. Indeed, several circuits and the Supreme Court recognize a futility exception to the finality requirement. ${ }^{84}$ Under this exception, "[a] landowner may avoid the final decision requirement if attempts to comply with that requirement would be futile." " "[T] he submission of a plan for development is futile if a sufficient number of prior applications have been rejected by the planning authority." ${ }^{86}$ At least one of the applications submitted by the developer must be meaningful and not exceedingly grandiose. ${ }^{87}$ While it may be difficult to determine "when,

regulations to the property at issue' from 'the government entity charged with implementing the regulations,' and sought 'compensation through the procedures the State has provided for doing so.'” (quoting Williamson County Reg'l Planning Comm'n v. Hamilton Bank, 473 U.S. 172, 186, 194 (1985))). This second requirement was not at issue in Del Monte Dunes.

81. Resolution Trust Corp. v. Town of Highland Beach, 18 F.3d 1536, 1546 (11th Cir.) (quoting Williamson, 473 U.S. at 191), vacated on other grounds, 42 F.3d 626 (11th Cir. 1994).

82. Suitum, 520 U.S. at 746.

83. MacDonald, Sommer \& Frates v. County of Yolo, 477 U.S. 340, 348 (1986). There is some question about exactly what constitutes final action in these cases. Indeed, the "case law is muddled" as to how many appeals a landowner must take of a permit denial and to whom. Thomas E. Roberts, Ripeness and Forum Selection in Land-Use Litigation, in TAKINGS AFTER DOLAN AND LUCAS, supra note 1, at 46, 53; see also id. (noting that repeated denials by a building inspector do not constitute a final action when appeal to a board of adjustment is available).

84. See MacDonald, 477 U.S. at 352 n.8.

85. Herrington v. County of Sonoma, 857 F.2d 567, 569 (9th Cir. 1988) (amending a decision after a rehearing en banc and holding that the landowner had satisfied the ripeness requirement where the county had rejected his proposal and drastically limited the allowable development), cert. denied, 489 U.S. 1090 (1989); see also Kinzli v. City of Santa Cruz, 818 F.2d 1449, 1454 (9th Cir.) (holding that "the submission of a development plan is excused if such an application would be an 'idle and futile act"' (citation omitted)), modified, 830 F.2d 968 (9th Cir. 1987).

86. Kinzli, 818 F.2d at 1454 .

87. See Herrington, 857 F.2d at 570; Kinzli, 818 F.2d at 1455. 
and how often, reapplication is necessary," ${ }^{, 88}$ it is clear that suspicions about the motives of local officials and the absence of a variance procedure are generally not sufficient to satisfy the standard for futility. ${ }^{89}$ Rather, the landowner bears the burden of persuading the court that the steps necessary to reach a final determination would be utterly futile. $^{90}$

As discussed above, the Ninth Circuit upheld the district court's invocation of the futility exception in Del Monte Dunes. ${ }^{91}$ This analysis was significant because it added to the confusion about whether the taking in this case was permanent or temporary by complicating the finality analysis.

\section{A TEMPORARY TAKING LEADS TO PERMANENT CONFUSION}

Because the developer was denied use of his land only for the time between the final permit denial and the sale of the property, the taking in Del Monte Dunes appears, on the surface, to be easily classified as temporary. In fact, the courts apparently looked no deeper in implicitly reaching that conclusion. At all stages prior to the Supreme Court, the parties and judges involved in the Del Monte Dunes litigation seemingly accepted that, if a taking occurred, it was temporary. However, the Ninth Circuit did not use the term "temporary taking" in either of its two opinions. Further, during oral argument before the Supreme Court, several Justices expressed concern about that assumption. Initially, Justice Breyer inquired, “[T]hat's what keeps bothering me. This is a temporary takings case, I take it, and everybody's arguing as if it's not, so I must be wrong, but why?" ${ }^{2} \mathrm{He}$ then asked the attorney for the United States, arguing as amicus curiae on behalf of the city, whether he was "saying this is not a temporary takings case." ${ }^{, 93}$ To this question, the attorney could only reply that he did not believe that the property was valueless. Indeed, the attorney was moved to state that "[t]he Court has not really spelled out what

88. Roberts, supra note 83 , at 54 .

89. See id. at 54-57 (discussing the confusing distinction between "meaningful" and "grandiose" proposals in assessing the futility of reapplication).

90. See Kinzli, 818 F.2d at 1455.

91. See supra note 36 and accompanying text.

92. Oral Argument, City of Monterey v. Del Monte Dunes, Ltd. (No. 97-1235), at *27 (visited Nov. 2, 1999) <http://ls.wustl.edu/ mandelke/Land_Use/del_oral.html> (on file with the Duke Law Journal).

93. Id. at $* 29$. 
the standards are" for determining whether a temporary taking has occurred. ${ }^{94}$

This confusion over the type of taking that occurred in $\mathrm{Del}$ Monte Dunes arises from two sources. First, Del Monte Dunes does not present the typical temporary takings scenario because a sale of the property, rather than a revocation of the land-use restriction, terminated the period during which the taking was effective. Second, even though compensation was to be awarded for a temporary period of time, the lower courts did not distinguish between permanent and temporary takings analysis in determining whether a taking had occurred. The litigation began before the developer sold the property to the city, and the taking could fairly have been characterized as permanent at that time. Because there is no clearly defined test for a temporary regulatory taking, the jury was instructed using permanent takings standards. Further, the Ninth Circuit specifically found that the city would most likely never permit the land to be developed. ${ }^{95}$ These factors indicate that the taking was permanent, even though compensation was sought for a limited time.

\section{A. Termination by Sale}

When the Supreme Court first recognized temporary regulatory takings, it defined the term to mean "those regulatory takings which are ultimately invalidated by the courts. ${ }^{, 96}$ In fact, in First English, the Court determined that "abandonment [of a land-use restriction] by the government requires payment of compensation for the period of time during which regulations deny a landowner all use of his land." Since that time, courts have consistently found takings to be temporary when they are terminated because regulations are invalidated or rescinded or the government exercises eminent domain. ${ }^{98}$ They have

\footnotetext{
94. Id. at $* 26$.

95. See supra note 46 and accompanying text.

96. First English Evangelical Lutheran Church v. County of Los Angeles, 482 U.S. 304, 310 (1987).

97. Id. at 318 .

98. See, e.g., Suitum v. Tahoe Reg'l Planning Agency, 520 U.S. 725, 734 (1997) (holding that a takings claim is ripe where a final decision forbidding development has been made by the regulatory agency); First English, 482 U.S. at 319-22; see also Lindfors, supra note 2, at 272 ("A temporary taking occurs when governmental activity or regulation denies a landowner all property use for a period of time and the regulation is later invalidated.").
} 
not, however, recognized that a taking can be made temporary by sale of the property by the landowner. ${ }^{99}$

This distinction might, at first glance, seem to be nothing more than semantic nonsense. However, it is not completely novel to regard the cause of termination as relevant to the takings inquiry. Indeed, it has been argued that governmental actions, when they are invalidated for being ultra vires, should not give rise to takings claims. ${ }^{100}$ While that opinion is based upon a belief that the Takings Clause applies only to "otherwise proper" governmental actions, ${ }^{101}$ the idea that the cause of the termination of the land-use restriction is relevant to determining the type of taking is applicable in Del Monte Dunes.

Moreover, the distinction does have important legal ramifications. Part of the rationale for recognizing temporary takings is that "[o]nce a court determines that a taking has occurred, the government retains the whole range of options already available - amendment of the regulation, withdrawal of the invalidated regulation, or exercise of eminent domain." ${ }^{102}$ In other words, a "landowner has no right under the Just Compensation Clause to insist that a 'temporary' taking be deemed a permanent taking." ${ }^{103}$ Thus, the taking is temporary because the government is allowed the flexibility to alter its circumstances. ${ }^{104}$ That flexibility is removed when the landowner is allowed to alter the nature of the taking by selling the property. Further, by recognizing a temporary taking in which a regulation was neither invalidated nor rescinded, the Court has expanded the realm of compensable temporary takings without acknowledging that extension.

99. It is important to note that Del Monte eventually sold the Dunes to the state of California. However, the sale was not conducted as an exercise of the state's power of eminent domain. See Savage, supra note 17, at 35.

100. See Matthew D. Zinn, Note, Ultra Vires Takings, 97 MicH. L. REV. 245, 245-46 (1998) (arguing that unauthorized state actions should not give rise to takings claims).

101. Id. at 249 (quoting First English, 482 U.S. at 318).

102. First English, 482 U.S. at 321.

103. Id. at 317 .

104. See Suitum v. Tahoe Reg’l Planning Agency, 520 U.S. 725, 738 (1997) (““[L]ocal agencies charged with administering regulations governing property development are singularly flexible institutions; what they take with the one hand they may give back with the other." (quoting MacDonald, Sommer \& Frates v. County of Yolo, 477 U.S. 340, 350 (1986))). 


\section{B. Permanent or Temporary Analysis?}

On the takings claim, the jury in Del Monte Dunes was instructed that "it should find for Del Monte if (1) all economically viable use of the property had been denied; or (2) the City's decision to reject Del Monte's development application did not substantially advance a legitimate public purpose." ${ }^{105}$ Because the jury gave a general verdict, there is no way to know on which of these grounds the jury made its decision. Nevertheless, it is clear that these standards are the ones established to determine if a permanent taking occurred. ${ }^{106}$

Use of those standards has found support among some members of the Court who have indicated "that temporary reversible 'takings' should be analyzed according to the same constitutional framework applied to permanent irreversible "takings." "107 It is certainly reasonable to use the same test to determine, as an initial step, if the governmental action rises to the level of a compensable taking. However, the Supreme Court never has stated that proposition explicitly. While it seems clear that the differences between permanent and temporary takings are most important when calculating just compensation, the Court has provided no guidance on the issue.

Further confusion was created in Del Monte Dunes by the application of the futility exception. ${ }^{108}$ Use of the futility exception required the developer to emphasize, and the court to scrutinize closely, each of the city's permit denials. This scrutiny created a record replete with references to the idea that the city was never going to allow residential development on the Dunes regardless of the development proposal. Thus, the reviewing court was left with the strong impression that, if the city effected a taking by not allowing development, it did so permanently. That is, the analysis of Del Monte's claim under the futility exception easily leads to the conclusion that any use or value of the property that was taken by the permit denials could not be returned because the city planning commission would not change its decision. Clearly, had Del Monte not sold the Dunes, the city could have changed its mind after trial and allowed development rather than exercise eminent domain. However, this idea was not discussed in the lower court opinions.

105. Del Monte Dunes II, 95 F.3d 1422, 1426 (9th Cir. 1996).

106. See supra note 46 and accompanying text.

107. San Diego Gas \& Electric Co. v. City of San Diego, 450 U.S. 621, 657 (1981) (Brennan,

J., dissenting); see also supra notes 70-79 and accompanying text.

108. See supra note 36 and accompanying text. 


\section{ClarificAtion, Not SEPARATE ANALYSIS}

Unfortunately, the Supreme Court was not required to resolve either of the issues discussed above. Rather, it simply accepted the lower courts' assumption that the taking was temporary and mentioned the issue only twice in its opinion. First, the Court found that "[t]he posture of the case [did] not present an appropriate occasion to define with precision the elements of a temporary regulatory takings claim ...."109 Similarly, the Court stated that because " $\mathrm{t}]$ he city did not challenge below the applicability or continued viability of the general test for regulatory takings liability .... [it would] decline the suggestions of amici to revisit these precedents." Court omitted an important step in the analysis and bypassed the opportunity to eliminate confusion.

That is not to say, however, that the Court should have designed an entirely separate test for situations like the one in Del Monte Dunes. The Court experimented with such a tactic when it established the new category of per se takings in Lucas. Unfortunately, however, the procedural efficiencies intended by that opinion have not been fully realized. ${ }^{111}$ Certainly, the decision has been hailed for simplifying certain categories of cases and for closing "the gap between physical and regulatory takings." ${ }^{\text {112 }}$ However, it has also been roundly criticized for its limited scope and for its further confusion of an already complicated area of the law. ${ }^{113}$ In fact, Professor Jed Rubenfeld is of the opinion that in Lucas, while "purportedly establishing a new bright-line rule to resolve certain takings difficulties, the Court actually has added yet another tortuous knot to an already convoluted doctrine." 114

The perceived deficiencies of the Lucas tests stem, at least in part, from their sweeping nature. Indeed, Justice Blackmun began his

\footnotetext{
109. Del Monte Dunes III, 119 S. Ct. 1624, 1644 (1999).

110. Id. at 1636 .

111. See Freilich et al., supra note 61, at 177 (noting that litigants still attempt to invoke the categorical rule when they have been deprived of less than all economically viable use of their property).

112. Bernard H. Siegan, Property And Freedom 149 (1997). Professor Siegan argues that Lucas significantly advanced freedom by protecting against legislative deprivations of property rights. See id.

113. See Freilich et al., supra note 61, at 177.

114. Rubenfeld, supra note 3 , at 1080.
} 
dissent in that case with the now-famous admonition that "[t]oday the Court launches a missile to kill a mouse." ${ }^{\text {115 }}$ In Del Monte Dunes, the Court did not need to be that ambitious. Initially, it should have recognized that Del Monte Dunes did not present a typical temporary takings case. The Court then could have stated explicitly that it was expanding the realm of compensable temporary takings to permit landowners to preclude the government's ability to nullify its land-use decision. Doing so would have resolved the confusion in this case, but it would have done little to simplify the distinction between permanent and temporary takings.

On the other hand, the Court might have carved an explicit niche in the existing analytical framework. It could have done so by recognizing that the taking, when it occurred, was permanent. Thus, had the developer not sold the Dunes, it would have been entitled to fair compensation for a permanent taking. Making this fact explicit, in turn, would have allowed the Court to explain why an analysis based on permanent takings doctrine was appropriate. The Court could then have explained that the sale of the Dunes by Del Monte to the state of California did not change the taking itself from permanent to temporary. Rather, it simply limited the time for which Del Monte was entitled to compensation. That is, because Del Monte Dunes does not concern an ordinance that was in place temporarily, there was no temporary taking. Rather, the permit denials effected a permanent taking for which the landowner was allowed recompense only for a limited time. Such a distinction makes sense because the Court has never before allowed a landowner to determine when a taking "ends." There is, however, nothing to prevent the landowner from limiting his compensation for that taking by selling the property.

Thus, the Court should have stated initially that the taking, if one occurred, was permanent, because the city did not have the opportunity to reverse its decision. It could then have determined whether the deprivation required compensation according to the framework described in Part II for establishing a permanent taking. Once the taking was established, the Court could have explained that by selling the property the developer limited the time for which he was entitled to

115. Lucas v. South Carolina Coastal Council, 505 U.S. 1003, 1036 (1992) (Blackmun, J., dissenting). Justice Blackmun reasoned that the alleged taking was a protection of health, safety, and welfare, which, as such, did not warrant compensation under the protection of the Fifth Amendment. See id. (Blackmun, J., dissenting). 
compensation. ${ }^{116}$ In this way, the Court would have made explicit its rationale for upholding the compensation award without drastically changing takings law. While such an explanation likely would not have affected the eventual outcome of the case, it might have alleviated significant confusion in future litigation.

\section{CONCLUSION}

Confusion of the sort found in Del Monte Dunes has led some analysts to complain that takings law is intractably convoluted. At least one commentator is of the opinion "that the current morass of Takings Clause jurisprudence demonstrates that the process for resolving cases has become more vital to society than seeking to perfect the substantive constitutional doctrines. Indeed, the notion that such doctrines can be perfected is a chimera no longer worth pursuing." 117 Suggestions to remedy the situation range from the passage of mandatory compensation laws ${ }^{118}$ to shifting the focus of the inquiry to the use of the property taken rather than the impact on the landowner. ${ }^{119}$

However, such sweeping changes to takings jurisprudence are not necessary. Rather, the Supreme Court is well equipped to develop a more explicit framework in which to resolve takings claims. Del Monte Dunes presented the Court with an opportunity to simplify future takings litigation by providing specific boundaries and particular rules to use when evaluating temporary takings. Unfortunately, by refusing to take that opportunity, the Court ensured that increasingly complex fact patterns will continue to complicate the landscape of takings jurisprudence.

116. Alternatively, the situation could have been explained as a new sort of temporary taking-one in which the landowner is permitted to preclude the city's nullifying its land-use decision. However, as discussed supra Part III.B, such a change would have significantly expanded the scope of temporary takings for which First English required compensation. See supra notes 97-104 and accompanying text.

117. Bruce Burton, Regulatory Takings, Private Property Protection Acts, and the "Moragne Principle:” A Proposal for Judicial-Legislative Comity, 49 S.C. L. REV. 83, 88 (1997). Professor Burton proposes the use of alternative dispute resolution combined with the problem-solving structures found in the Private Property Protection Act to relieve the uncertainty of litigation in takings proceedings. See id.

118. See id.

119. See Rubenfeld, supra note 3, at 1080-81 (““[R]egulatory takings' occur ... when their effect is ... to put [private] property to a particular state use."). 